\title{
Public Health is Politics
}

\author{
Jan Sundin ${ }^{1}$
}

Published online: 10 May 2019

(C) The Author(s) 2019

\begin{abstract}
'Public health' investigates the determinants of health, born during the Enlightenment in the seventeenth/eighteenth century. But 'public health' is also policies, aiming at the improvement of a population's health. There is a mutual interchange between public health as science and as politics. A brief historical background is followed by an analysis of the impacts of political changes during the first two decades of the twenty first century in Sweden. In 2005, a policy document accepted by all political parties except for the Moderate Party highlighted socio-economic factors and structural reforms to decrease the health gaps in the population. The general election in September 2006 resulted in a new majority in the parliament and a center-right coalition government, including the Moderates and three parties that had approved of the 2005 document. In 2007 a "new public health policy" was introduced. Its priority lists stressed individual behavior and the new policy should be incentives to work instead of "allowances". The Public Health Institute got instructions in accordance with the new policy. The ten years following this policy change has seen public health policies and attitudes to research shifting almost year by year. The new policy met a counter-stream from the very beginning. Influenced by Michael Marmot's WHO Commission on health inequalities, regional commissions started in Sweden, Recommendations how to decrease social health gaps was adopted with almost no opposition by regional health boards in 2012-2013. But new problems were now occupying politicians and media-how to finance the growth of the old, multi-sick part of the population and increasing costs for new medical technologies and drugs. Public health as an academic discipline was in the middle of this fluctuating political landscape with direct effects on what has been considered worth listening to or support by public money.
\end{abstract}

Keywords Public health · Policy making $\cdot$ Contemporary history

Jan Sundin

jan.sundin@liu.se

1 Emeritusakademin, HusEtt, Linköping University, 58183 Linköping, Sweden 


\section{Enlightenment and Public Health}

Public health as science and politics in Sweden dates to the eighteenth century. ${ }^{1}$ For Confucius, 2500 years ago, a bad king could bring all kinds of misfortunes, including disease and death, upon his people. This idea was also part of European thinking, at last until the seventeenth century. It was also in the Early Modern period that the Prince/State began to fight the plague by isolation, quarantine and other attempts to keep the epidemic outside the borders. To a certain degree, the state had then accepted a responsibility, if limited, for the public health. But public health as a concept, a target of study and collective action is for several reasons said to be born and developed during the eighteenth century. It was an offspring of the Enlightenment, empirical with a trust that the expansion of knowledge could be used to further the good and hamper the evil. Making life better for individuals was of course one reason to take positive action. However, the prime goal for the State was often to breed a large, healthy population who could pay taxes and produce soldiers.

As policy and a target of research, public health was met with enthusiasm by the Swedish State and its academics. The botanist Carl Linnaeus and his colleagues convinced the authorities to start the Tabellverk, an organization for collection and analysis of yearly tables on mortality by sex, age and causes of death from all of the country's about 2500 parishes from 1749 and onwards. The access to vital data, including the population at risk every fifth year by sex and age, stimulated its use. As in other European countries epidemiology and ideas how to fight the recurrent epidemics were born.

Data revealed the connection between social status and mortality, especially in the cities. One explanation emphasized factors outside the power of the individual, i.e. one's health was often a result of being in a situation one could not be blamed for. The opposite explanation said that poverty and other negative factors were usually the individual's own fault. Only a few who had been unfortunate, for instance being blind since birth, were 'deserving poor' with a moral right to be helped. The rest had to be disciplined with a whip rather than a carrot. These two opposite views were part of a common debate in western Europe during the nineteenth century. This discussion was the first example of what was later called the "structural" versus the "individual" theory in public health. Current medical theories of importance for the fight against disease and death were, however, not preoccupied with the moral side of death. The big bulk of mortality was obviously caused by infectious diseases and until the birth of bacteriology during the last decades of the nineteenth century, these diseases were thought to spread through contagion, particles migrating from one individual to another, or by miasma, a kind of vapor emerging from dirty swamps or stench, attacking a person's lungs and stomach. Although rather crude from a modern point of view, these theories contributed to better cleanliness and health. They became an argument for the hygienic era, with social engineers building pipelines for water, sewage systems and a cleaner and healthier city. Such

\footnotetext{
1 For the story before year 2000 see Sundin and Willner (2007).
} 
was the situation when Robert Koch and Louis Pasteur initiated the revolution of bacteriology during the last decades of the nineteenth century. It strengthened the authority of science and the arguments for hygienic reform. Public health science and policy became a multidisciplinary trade with medicine, epidemiology and engineering serving a healthier society.

\section{Social Hygiene}

It did not take long, however, before the prestigious concept was also adopted by those who presented theories about a population composed of biologically more or less "valuable" individuals. The Italian Cesare Lombroso's idea that you could distinguish criminals by their physical features became widely accepted in forensic medicine around 1900 and preceded the racial theories of the twentieth century. In Sweden, it led to the establishment of an institute for race hygiene in 1922 without political opposition. Social medicine, a relatively new discipline, also got its proponents of "social hygiene". A well-known representative in Sweden was Olof Kinberg, professor in forensic psychiatry, influential supporter of the inter-war law about forced sterilization and supportive of eugenics.

In 1938, the novelist Ludvig Nordström made a famous series of radio reports and wrote a book about 'Dirty Sweden". ${ }^{2}$ In the spirit of nineteenth century social engineers, its purpose was to show that many in the countryside lived in deplorable hygienic conditions. However, putting this observation in a wider context, the author had adopted more current views. In the final, conclusive radio program, he explained that much of the dirt was a product of indolence among the poor. They had become lazy because of too generous subsidies from the State. Generally, there were too many impregnated by a "relief mentality", 3 a concept that is kept alive in the political arguments of today, advocating individual rather than structural policies.

\section{The People's Home}

On the other side of the debate, Per-Albin Hansson (prime minister 1932-1946) gave a speech in the parliament in 1828, introducing "the People's Home" as an antithesis of "relief mentality": "The good home does not know of privileged or slighted, no pets and no step children. In the good home is equality, concern, cooperation and helpfulness - applied on the large people's and citizen's home this would mean the knocking down of all social and economic barriers." 4 The inter-war period was a political break-through for the social democrats and the social liberals in parliament and government. However, the prime goal was to fight depressions and unemployment, and public health as science, policy and practice were not on top of the list.

\footnotetext{
2 Ludvig Nordström (1938).

3 Swedish:"Understödstagaranda".

4 Per Albin om Folkhemmet (1989).
} 
Instead, the means to realize the goals of the social democrat's State came after 1945. Swedish economy was excellent, having its infrastructure intact and ready to export a diversity of goods asked for by other countries that had suffered from the war. For decades the party managed to stay in power permanently, from 1976 to 2006 sometimes interrupted by middle-right coalitions. Politically, public health was usually seen as part of the welfare state, accepted by a political majority. The policy document signed in 2005 illustrates this unity. The "new public health policy" in 2007 meant that the Moderate Party had convinced three other parties in the coalition to change the priorities.

\section{A New Public Health Policy}

In August 2007, an article in Göteborgs Tidningen was titled "Shut down the Public Health Institute". It criticized what it described as restrictions of the individual's free choice, recommended by the institute and put in place by the previous government. Giving several examples, it concluded that the institute was "part of a bureaucracy financed by taxes - the most primitive and uncalled-for stately care, an authority instructed to educate adult citizens".

The article was not a shot in the dark. One month earlier, the coalition that took over government after the election 2006 decided to close the Institute for Working Life (IWL) with about 400 employees on different places in Sweden. IWL's research agenda should in the future be handled by the universities but no money was granted in the budget. Its current form was established by the left-wing government in 1995 but it had a forerunner in the Centre for Working Life, founded in 1777. Two authors declared in 1778 that the reason was that "the control over research will be a central issue in the eighties, an important part of the democratization of the working life". One of its strongest proponents was the Trade Union Confederation, declaring that it looked for a policy based on research. ${ }^{6}$

A report of a committee with representatives of all parliamentary parties had been published as late as 2005 by the Public Health Institute. ${ }^{7}$ It defined 13 target areas for health and was accepted by all parties except the right-wing Moderate Party. The emphasis was put on structural welfare factors, such as "participation and influence in society", economic and social safety" and "a safe and good childhood". Individual lifestyle - physical activity, eating habits and drug abuse - came at the end of the priority list. Three years later, in 2008, "A Renewed Public Health Policy" was adopted by the political majority, turning the priority list of 2005 upside down. ${ }^{8}$ The government declared that the foundations of public health policy shall be "the individual's need of integrity and freedom of choice". Concrete reforms should "strengthen and support parenthood", "intensify prevention of suicides", "promote

\footnotetext{
5 GöteborgsTidningen (2007).

6 Lag och Avtal (2006) and Ehn and Sandberg (1978).

7 Folkhälsopolitisk Rapport (2005).

${ }^{8}$ Regeringsproposition (2007).
} 
good eating habits and physical activities" and "minimize the use of tobacco", i.e. mainly to influence the individual's knowledge, attitudes and behavior.

The Moderate Party dominated the new government. It also made the most visible imprints on this public health document. "Social exclusion" was used as the key element defining the over-representation of bad health in groups with low education, the unemployed and those on long-term sick-leave. This concept had been introduced by the winning coalition in the 2006 election campaign. A successful fight against this exclusion should be based on bringing people back to work and self-support using whips rather than carrots. It should for instance be tougher to get paid sick leave, thereby creating "an own, clear responsibility to get back to work". Other reforms were also mentioned that should strengthen "The Primacy of Work" versus exclusion. The message was that the individual, not structural factors beyond the individual's reach like wealth, had the fate in her hands.

To "have an influence over everyday life by freedom of choice", promoted by privatization of different sectors in healthcare was a strategy shared by all four parties in the coalition. Other coalition parties were also allowed to influence the summary. Educational reforms were at the heart of the liberals, hence a reference to the connection between low education and bad health. Voluntary work was emphasized as good for a healthy social capital, a sense of belonging and fellowship - a declaration close to central issues among the Christian Democrats. "Influence over everyday life" through free choice and privatization of different sectors of care was also emphasized. It was very clear that the "renewed public health" was an application of the general political agenda of the new government.

The implications of the new policy for public health research were considerable. The institute was not closed, even if it had been a possible option of the minister of health. The previous government had already decided that the institute should move from Stockholm to a small town in the north, a deliberate intention to decentralize and strengthen the labor market in the periphery. Whether it was the decisive factor or not, a closure had become a political risk. Few researchers did, however, follow the institute to its new location. The directives of the ministry of health did also limit the sphere of research. More emphasis was gradually put on medical epidemiology at the expense of an analysis of social, structural factors related to health. No more money was for instance granted for publishing a statistical report every fourth year.

In theory, the closure of the Institute for Working Life and the reorganization of the Public Health Institute would only mean that studies of these two fields should be conducted and evaluated within the universities. But a considerable part of the research financed by the institutes had already been conducted at or in collaboration with universities. When the state delimited its direct support of research to medical and epidemiological aspects, most social scientists had to look for other research areas. The change from a left-center to a center-right government and its "renewed" public health policy meant a delimitation of a research field to "politically neutral" subjects from ideological points of view. Consequently, social science studies of structural factors saw its resources shrinking dramatically, further underlined when

9 "Utanförskap", being outside society. 
it was merged with The Swedish Institute for Disease Control in 2014 under a new name, The Public Health Agency.

\section{Regional Marmot Commissions}

The political benefits seemed obvious from the point of view of the new government. However, history tells us that public health policy is formulated in an interaction between ideologies, science and manifested realities. A dominant political hegemony might decide which "science" should be funded and listened to. But social realities and scientific perspectives can change quickly, sometimes more rapidly than expected. Within less than four years and before the next election, the targets of public health in the media and political debate were once more seen as something more than epidemics and individual behavior.

Several events contributed to the change. An economic crisis in the western world begun to have negative impacts on unemployment and other social problems. International research on the connection between economic inequality and health differences had been going on for more than a decade. ${ }^{10}$ Michael Marmot, a British peer and professor in medicine, published several studies, for instance on the connection between social status, heart disease and life expectancy. He became the leader a WHO Commission on the Social Determinants of Health. Some studies for the commission were made by Swedish researchers. ${ }^{11}$ They were met with skepticism by the ministry of health. At the same time, the Swedish translation of Michael Marmot's book in 2006 on "the status syndrome" was praised by the media. ${ }^{12}$ Their coverage was also intensive when the WHO commission delivered its final report "Closing the Gap in a Generation" in 2008. ${ }^{13}$ One of the commission's conclusions was the growing importance of psychosocial factors for increased health differentials in populations. This came at the same time as epidemiologists and medical agents referred to statistics about widening social differentials and a significant increase of mental health problems in Sweden.

Regional health boards were the first to respond and started several "Marmot commissions" in 2011-2013. Their data illustrated the social differentials for heart disease and other serious health problems in the regions. It had for instance been known before that there was a difference in life expectancy between the richest versus the poorest communities in the Stockholm region. However, it had not been understood that the magnitude of the difference was almost 10 years in the worst cases. The regional commission for the county of Östergötland, among others, discovered that the health differential showed itself stepwise among its 13 communities. ${ }^{14}$ The commissions delivered joint recommendations on how to integrate the

\footnotetext{
10 Wilkinson and Marmot (2001) and Putnam (2001).

11 Lundberg et al. (2008).

12 Marmot (2006).

13 Marmot (2008).

14 Region Östergötland (2014).
} 
idea of equality and health in every political sphere. Politicians from all parties had participated in these commissions, one way or the other. It meant that the conclusions were followed by formal policy declarations with little resistance.

After 2013, public health research was theoretically and methodologically in a favorable position in Sweden. There had been a fruitful merge between biomedicine, psychology and social science. A general theory was accepted about the connection between society and health, whilst many of its implications had yet to be understood. However, 4 years later, Sweden is facing another election. Social determinants and health are sometimes mentioned in political fora but usually from a new angle. How to make the immigrants become Swedes is the most acute agenda, by political parties as well as in opinion polls among the voters. Health is also a priority, but the main concern is how to get rid of the queues for care of serious medical needs. New medical technologies, particularly new drugs tend to increase costs. Hence, the interest in research is directed towards economy and administration. Social determinants of health are commonly accepted but the general policy documents are thought to have settled the issue.

\section{Conclusion}

As an interdisciplinary arena, the funding of public health research has depended largely on public money-at specific institutes or from sources open to any researcher. The Swedish Council for Planning and Co-ordination of Research was led by researchers and specifically designed to support interdisciplinary projects. But the golden era of interdisciplinary research in Sweden was in the 1980s and consequently a new minister of education decided to close it in 1992. Public health has been a target of political interest and dispute from its very birth during the eighteenth century and onwards. The central question was already in the nineteenth century whether individual, free choice or structural forces beyond the power of the individual, was the predominant factor causing the observed social differentials of health in a population. Conservatives and adherents of laissez-faire tended to believe in the individual's behavior and own responsibility. Social liberals and politicians on the left side have emphasized the structural explanation. There has of course not been any open censorship regulating what, how and to which extent academic research should be engaged in trying to increase the knowledge and understanding of relationships between health and society. But a great deal of funding has come through politically controlled channels. The latest Swedish example of the impact of political goals on public health research and practical policy came after a change of political majority in parliament in 2007.

Open Access This article is distributed under the terms of the Creative Commons Attribution 4.0 International License (http://creativecommons.org/licenses/by/4.0/), which permits unrestricted use, distribution, and reproduction in any medium, provided you give appropriate credit to the original author(s) and the source, provide a link to the Creative Commons license, and indicate if changes were made. 


\section{References}

Ehn, P., \& Sandberg, Å. (1978). Forskning på arbetsplatsen. Stockholm: När Var Hur.

En förnyad folkhälsopolitik. (2007). Regeringsproposition, p. 110.

Folkhälsopolitisk Rapport. (2005). Stockholm: Statens folkhälsoinstitut R 2005, p. 5.

GöteborgsTidningen 2007-08-17: Retrieved May 15, 2018, from https://www.expressen.se/gt/ledare/laggner-folkhalsoinstitutet/

Lag och Avtal. (2006) Retrieved May 15, 2018, from https://www.lag-avtal.se/nyhetsarkiv/arbetslivsinsti tutet-laggs-ned-6560845.

Lundberg, O., et al. (2008). The Nordic Experience: Welfare States and Public Health (NEWS), Centre for Health Equity Studies (CHESS). Stockholm: Stockholms universitet/Karolinska institutet.

Marmot M. (2006). Statussyndromet. Hur vår sociala position påverkar hälsan och livslängden. Stockholm: Natur och Kultur, Stockholm.

Marmot, M. et al. (2008).Closing the gap in a generation: Health equity through action on the social determinants of health. Final report of the WHO Commission on Social Determinants and Health 2005-2008. WHO. Geneva.

Nordström, L. (1938). Lort-Sverige. Stockholm.

Östgötakommissionen för jämlik hälsa. (2014). Region Östergötland, Linköping.

Per Albin om Folkhemmet [Per Albin Hanssons tal om folkhemmet-medborgarhemmet i riksdagens remissdebatt 1828]. Stockholm, Medica Press 1989.

Putnam, R. D. (2001). Bowling alone: The collapse and revival of American community. London: Simon and Schuster.

Sundin, J., \& Willner, S. (2007). Social change and health in Sweden 250 years of politics and practice (p. 21). Stockholm: Statens Folkhälsoinstitut. R.

Wilkinson, R., \& Marmot, M. (2001). Social determinants of health. The solid facts. 2003. Copenhagen: WHO.

Publisher's Note Springer Nature remains neutral with regard to jurisdictional claims in published maps and institutional affiliations. 